Ann. Biol. anim. Bioch. Biophys., I976, 16 (3), 443-45I.

\title{
PRECOCIOUS PUBERTY IN FEMALE RATS : ON THE MODE OF ACTION OF HYPOTHALAMIC LESIONS
}

\author{
D. DE ZIEGLER ('), M. WILKINSON and K. B. RUF \\ Department of Physiology, University of Geneva, \\ École de Médecine, \\ 1211 Geneva 4 (Switzerland)
}

\section{SUMMARY}

Progesterone-induced release of luteinizing hormone (LH) and of follicle-stimulating hormone (FSH) was studied in immature female rats 3 days after an injection of estrogen or after the placement of an electrolytic lesion in the basal hypothalamus. Both types of sequential treatment elevated plasma concentrations of LH more than 20-fold as compared with controls. Plasma FSH concentrations increased by a factor 3 after the sequence brain lesion-progesterone and by a factor 5 after the combined hormonal treatment. Uterine weights, determined as a cumulative index of prior exposure to endogenous or exogenous estrogen, were similarly increased in both groups.

It is concluded that this type of brain lesion is able to replace an injection of estrogen in priming an immature female rat for the subsequent progesterone-induced gonadotropin release and that a unilateral hypothalamic lesion placed, on day 23 of life, near the origin of the pituitary stalk, is the approximate equivalent of ro $\mu \mathrm{g}$ estradiol benzoate injected subcutaneously at that time. These findings support our view that brain lesions advance sexual maturation in the female rat via the precocious activation of ovarian steroidogenesis rather than by removing neural restraints upon the reproductive system.

The observation originally made by DoNOVAN and VAN DER WERFF TEN BOSCH (I956) that sexual maturation in the female rat can be advanced by small electrolytic lesions placed in certain areas of the brain has been confirmed and extended by various investigators (see DONOVAN and VAN DER WERFF TEN BOSCH, I965 ; CRITCHLOW and BAR-SELA, I967; RAMIREZ, I973; DAVIDSON, I974 for review). In contrast, the mechanism by which such lesions are able to stimulate the reproductive system has remained obscure (DAvidson, I974).

(1) Address for correspondence : Fondation pour Recherches médicales, 64, avenue de la Roseraie, I 2 I Genève 4 (Switzerland). 
In previous studies, we have found : a) that lesion-induced precocious puberty in the rat is associated with a rapid and sustained increase in ovarian steroidogenesis (RUF et al., I974; YoungraI et al., unpublished), b) that small amounts of exogenous estrogen administered in conjunction with the brain lesion may exert a facilitatory effect (KITCHEN et al., I975; RUF et al., in press), and c) that brain lesions and injections of small amounts of estrogen both increase the ratio between luteinizing hormone $(\mathrm{LH})$ and follicle stimulating hormone (FSH) in anterior pituitary gland and in plasma over subsequent days (KITCHEN et al., I975; YoungLAI et al., unpublished). From these findings, we conclude that ovarian steroids, in particular estrogen, are important mediators of the effect of brain lesions on sexual maturation and that the development of the positive (stimulatory) feedback to estrogen is a crucial component of this process.

In the immature female rat, the ability to respond to an injection of estrogen with a discharge of LH (CALIGARIS et al., I972) and of FSH (CAL,IGARIS et al., I973) matures around day 28 of life. This pattern of response can be induced in younger animals, from about $2 \mathrm{I}$ days onwards, provided that they have been exposed to a " priming " injection of estrogen some 3 or more days before the application of the evoking stimulus (CALrgaris et al., 1972, 1973). Infusion experiments have also shown that prolonged exposure to estrogen is able to induce the maturation of this positive feedback system (STEELE and WEISZ, I974). The nature of this maturational process is yet to be defined; it appears that both cerebral and pituitary sites must be considered (SMrth and DAvidson, I974; Döcke and DÖRNER, I974) and that estrogen is also required for the maturation of the ovary itself (REITER et al., I972; MERK et al., I972).

In estrogen-primed immature rats, the gonadotropin surge can be induced either by an appropriately timed second injection of estrogen or by the administration of progesterone, the latter treatment being the more efficient one (CALIGaRIs et al., I972, I973). The main purpose of this study was to compare the priming efficiency of an injection of estrogen with that of a brain lesion in such an experimental design. Our results indicate that on day 23 a brain lesion can substitute fully for the priming effect of estradiol in terms of subsequent progesterone-induced $\mathrm{LH}$ release, whereas it is less efficient in promoting subsequent FSH release. The data are in line with our view (RuF et al., r974) that the effect of brain lesions on sexual maturation of the female rat is primarily mediated by ovarian steroids liberated in response to the brain stimulus.

Part of these findings have been published in preliminary form (RUF et al., I975 a).

\section{MATERIALS AND METHODS}

Female albino rats (Sprague-Dawley derived SIV-50) of certified age were obtained at $2 \mathrm{I}$ days of age and caged in groups of 8 under conditions of controlled illumination (lights on from o70o-I90o h). On day 23, they were evenly distributed over different experimental groups on the basis of their body weight (range 57-7 I g). Around noon, they were either primed with ro $\mu$ g estradiol benzoate (EB) (in peanut oil, $0.2 \mathrm{ml} \mathrm{s.c.)} \mathrm{or} \mathrm{subjected} \mathrm{to} \mathrm{a} \mathrm{unilateral} \mathrm{electrolytic}$ lesion situated near the origin of the hypophysial stalk. The technique of placement of lesions - also referred to as " electrochemical stimulation" (EVERETT and RADFORD, I96r) - and the his- 
tological appearance of the lesion site have been described in full elsewhere (RuF $e t$ al., I974). Briefly, rats were-anaesthetized with ether, placed in a stereotaxic frame, and an insulated steel electrode (outside diameter $0.25 \mathrm{~mm}$ ) with a bare tip of about $\mathrm{I} \mathrm{mm}$ was lowered into the area of the left arcuate/ventromedial nucleus. A direct anodal current of $0.5 \mathrm{~mA}$ was passed for $I_{5} \mathrm{sec}$ $(7.5 \mathrm{mC})$. On average this operation was completed in less than $3 \mathrm{~min}$, and the period of anaesthesia did not exceed $5 \mathrm{~min}$. On day 26 , at noon, animals were injected with I $\mathrm{mg}$ progesterone (in peanut oil, $0.2 \mathrm{ml}$ s.c.) and decapitated exactly $5 \mathrm{~h}$ later (CALIGARIs et al., I972, I973). Plasma was stored at $-30^{\circ} \mathrm{C}$ and assayed for $\mathrm{LH}$ and FSH concentrations using NIAMDD-NIH radioimmunoassay kits. In a variation of this experimental design, the progesterone injection was replaced by an injection of Io $\mu$ g EB at noon on day 25, the time of sacrifice remaining the same (CAligaris et al., 1972, I973). After decapitation, brains were fixed in ro p. roo formaline/saline for subsequent histological verification of lesion sites. Anterior pituitary glands were dissected free, weighed and frozen for determinations of gonadotropin concentrations. Ovaries and uteri were blotted on filter paper and weighed.

\section{RESULTS}

\section{I. - Progesterone-induced $L H$ release in rats primed with an injection of $E B$ or with a brain lesion}

Figure I illustrates that animals primed with an injection of EB on day 23 and then injected with progesterone on day 26 exhibited high plasma concentrations of $\mathrm{L} H$ when sacrificed $5 \mathrm{~h}$ later $(7 \mathrm{I} 8 \pm \mathrm{I} 07 \mathrm{ng} / \mathrm{ml} ; \mathrm{N}=8$ for all groups). Plasma
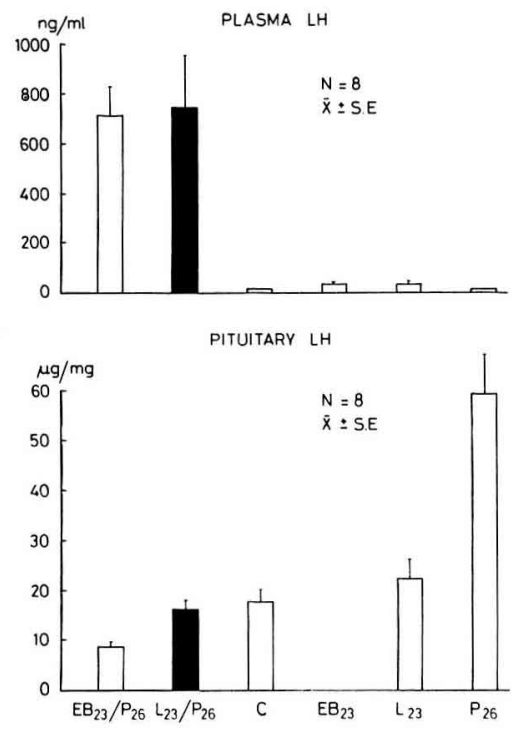

FIG. I. - Plasma and pituitary $L H$ concentrations in female rats

Indices refer to the age (in days) at which treatment was applied.

All animals were sacrificed around $\mathrm{r} 7$ oo $\mathrm{h}$ on day 26 of life

LH concentrations were equally high $(743 \pm 209 \mathrm{ng} / \mathrm{ml})$ when the injection of EB had been replaced by a unilateral hypothalamic lesion. In contrast, in untreated controls of the same age and in (unprimed) rats treated with progesterone only, plasma $\mathrm{L}_{\mathrm{H}}$ values were found to be below the limit of sensitivity of the assay system 
used ( $<$ I5 ng/m1). Plasma $\mathrm{L}_{1} \mathrm{H}$ concentrations were detectable and of similar magnitude $77 \mathrm{~h}$ after an injection of $\mathrm{EB}$ on day 23 alone $(35 \pm 2 \mathrm{ng} / \mathrm{ml})$ or after the placement of a brain lesion alone at that time ( $35 \pm$ ro $\mathrm{ng} / \mathrm{ml}$ ). From these results, it is concluded that an injection of Io $\mu \mathrm{g} \mathrm{EB}$ and a brain lesion are approximately equipotent in priming the LH-release system in these developing rats, both with respect to " spontaneous " release and with regard to the subsequent triggering action of progesterone.

Pituitary I,H concentrations (fig. I) differed considerably in these experimental groups. After the combined hormonal treatment they were significantly $(p<0.005)$ lower than the values found in all other groups. A brain lesion on day 23 did not significantly increase pituitary stores above control values, but a large increase $(p<0.00 I)$ was noted in (unprimed) animals treated with progesterone only. These data confirm that the releasing action of progesterone is dependent on prior exposure of the system to estrogen and indicates that the massive $\mathrm{LH}$ release induced by the $\mathrm{EB} /$ progesterone treatment is not fully compensated for by increased synthesis, whereas the brain lesion is better able to maintain pituitary stores in the face of increased release.

\section{2. - Progesterone-induced $F S H$ release in rats primed with an injection of $E B$ or with a brain lesion}

As shown in figure 2 , the combined hormonal treatment was most effective $(p<0.05$ as compared with all other groups) in elevating plasma concentrations of FSH $(980 \pm 9 \mathrm{I} \mathrm{ng} / \mathrm{ml})$. The sequence brain lesion/progesterone induced a rise (to $565 \pm \mathrm{I} 44 \mathrm{ng} / \mathrm{ml})$ which was significant $(p<0.05)$ as compared with controls,

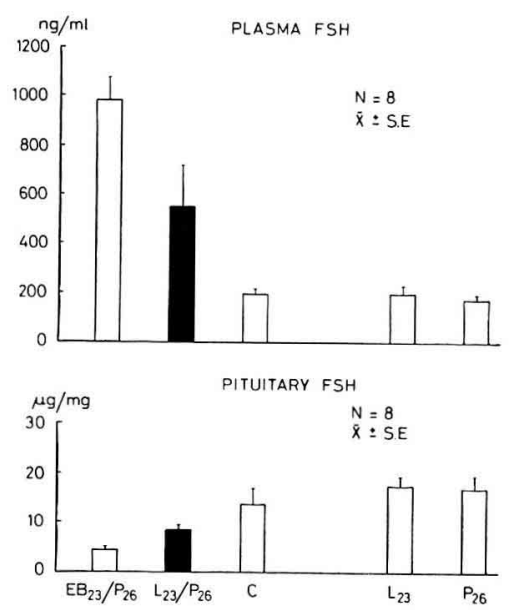

FIG. 2. - Plasma and pituitary FSH concentrations in female rats Same animals as in figure I

but was clearly less pronounced than that achieved with the former approach. Neither the brain lesion alone nor any of the single hormone injections led to significant increases in circulating plasma FSH. With respect to pituitary FSH concentrations (fig. 2) results were similar to those of $\mathrm{LH}$, except that the treatment with 
progesterone alone did not lead to a significant increment. These data are in line with earlier observations (KITCHEN et al., I975) that brain lesions favor the release of $\mathrm{LH}$ over that of FSH.

\section{3. - Uterine hypertrophy in rats primed}

with an injection of $E B$ or with a brain lesion

The determination of uterine weights at the time of sacrifice affords a convenient method for the quantitative estimation of prior exposure of different experimental groups to endogenous or exogenous estrogen. Figure 3 indicates that the combined hormonal treatment and the sequence brain lesion/progesterone resulted in similar degrees of uterine hypertrophy. EB treatment on day 23 only, and brain stimulation only, likewise had comparable effects on uterine growth. In contrast, uterine weights were significantly $(p<0.00 \mathrm{I})$ lower in untreated controls or in (unprimed) animals having received progesterone only on day 26.

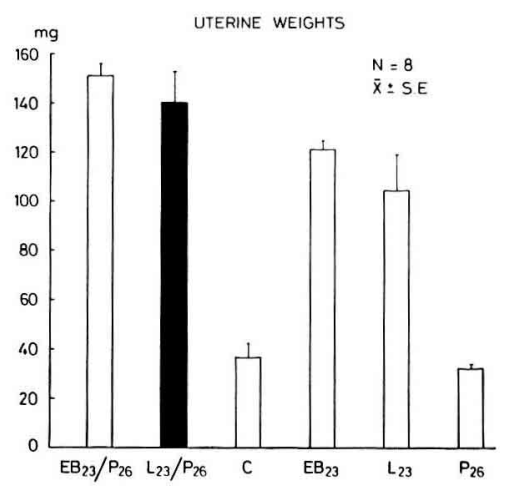

FIG. 3. - Uterine weights in female rats Same animals as in figures $\mathbf{I}$ and 2

On the basis of these data, it can again be concluded that the brain lesion is the approximate equivalent of Io $\mu \mathrm{g} \mathrm{E}, \mathrm{B}$ and that progesterone exhibits positive feedback effects only after prior exposure of the system to estrogen.

\section{4. - EB-induced gonadotropin release in rats primed with a brain lesion or with $E B$}

Immature estrogen-primed rats discharge gonadotropins also in response to an appropriately timed second injection of estrogen, but the magnitude of this response is less than the one triggered by progesterone (CALIGARIS et al., I972). When rats were given 2 injections of ro $\mu \mathrm{g} \mathrm{E,B}$, one on day 23 , the other on day 25 , all endocrine parameters determined in the afternoon of day 26 showed considerable scatter (table I). Animals in which the first injection of $\mathrm{EB}$ had been replaced by a brain lesion differed from this population only in that their pituitary LH concentration was significantly increased ; both approaches proved equally efficient in elevating plasma LH concentrations and uterine weights above controls. Since a single 
injection of EB on day 23 did not trigger a discharge of $\mathrm{LH}$ on day 26 (fig. I), its ability to do so in older animals was tested. EB injected on day 24 did not lead to a significant increase in plasma $\mathrm{LH}$, but a considerable increase over (nondetectable) control values was seen when the steroid was administered on day 25 (table I).

TABLE, I

Effects of various types of estrogen treatment on the reproductive system of female rats

\begin{tabular}{|c|c|c|c|c|c|c|}
\hline Type of treatment & $\mathrm{N}$ & $\begin{array}{c}\text { Plasma LH } \\
\text { (ng/ml) }\end{array}$ & $\begin{array}{c}\text { Plasma FSH } \\
(\mathrm{ng} / \mathrm{ml})\end{array}$ & $\begin{array}{c}\text { Pituitary LF } \\
(\mu \mathrm{g} / \mathrm{mg})\end{array}$ & $\begin{array}{c}\text { Pituitary } \\
\text { FSH } \\
(\mu \mathrm{g} / \mathrm{mg})\end{array}$ & $\begin{array}{l}\text { Cterine weights } \\
(\mathrm{mg})\end{array}$ \\
\hline $\mathrm{EB}_{23} / \mathrm{EB}_{25} \ldots \ldots$ & 8 & $294.1+2 ! 11$ & $2.26 .9 \pm 45.1$ & $36.5 \pm 5.3 f$ & $9.4 \pm 1.3$ & $199.6 \pm 13.1^{f}$ \\
\hline $\mathrm{L}_{23} / \mathrm{EB}_{25} \ldots \ldots$ & 8 & $612.7 \pm 298.3^{a}$ & $344.1 \pm 95.1^{b}$ & $56.8 \pm 3.7 c$ & $14.2 \pm 1.1 d$ & $168.2 \pm 13.3^{e}$ \\
\hline $\mathrm{EB}_{24}$ only & 8 & $23.8 \pm 3.5$ & & & & $102.6 \pm 2.9$ \\
\hline $\mathrm{EB}_{25}$ only $\ldots \ldots \ldots$ & 8 & $1-1 \cdot 6 \pm 50.9$ & $200^{\prime} 4 \pm 17.9$ & $51.8 \pm 5.5 f$ & $15.1 \pm 3.11$ & $91.9 \pm 5.5 f$ \\
\hline Untreated controls & 8 & $<15$ & $198.5 \pm 15.7$ & $18.1 \pm 2.0$ & $13.7 \pm 3.2$ & $36.7 \pm 5.5$ \\
\hline
\end{tabular}

$a: p>0.3$

$b: p>0.2$.

$c: p<0.001$;

$d: p>0.10$

$e: p>0.30$, as compared to combined hormonal treatment ;

$f: p<0.05$ as compared to untreated controls.

These data indicate that also in this test system, the brain lesion has a priming effect which is comparable to the injection of $10 \mu \mathrm{g} \mathrm{EB}$ and that a progressive maturation of the positive feedback system for $\mathrm{L}_{\mathrm{H}} \mathrm{H}$ release takes place during the observation period.

\section{DISCUSSION}

In this study, the priming effect of a dose of ro $\mu \mathrm{g} \mathrm{EB}$ administered to immature rats on day 23 of life was compared with the priming effect of a hypothalamic lesion placed in animals of the same age. Judged on the basis of the $\mathrm{LH}$ release induced by a subsequent injection of progesterone or by a (second) injection of EB (CALIGARIS et al., 1972), both treatments were found to be of equal estrogenic potency. In contrast, the brain lesion proved less efficient than the injection of $\mathrm{EB}$ in priming the system for subsequent progesterone-induced FSH release (CALIGARIs et al., 1973).

The mode of action of brain lesions in advancing sexual maturation in the female rat has been discussed for many years (DAvidson, 1974). It is generally held that these lesions remove inhibitory brain influences upon the reproductive axis, but a possible role of estrogen in the mediation of this lesion effect has been suggested earlier by RAMIREZ and SAWYER (I965). Our demonstration that brain 
lesions induce an increase in ovarian steroidogenesis which is demonstrable as early as I $h$ after their placement and which is sustained over subsequent days (RUF et al., 1974) has added further weight to this suggestion. In prepubertal (FERIN et al., I969) as well as in sexually mature (BROWN-GRANT et al., 1970) female rats, the essential role of estrogen in triggering an ovulatory surge of $\mathrm{L}_{\mathbf{H}} \mathrm{H}$ is well established. Other studies have shown that this positive feedback system is already functional before puberty (CALIGARIS et al., 1972, 1973) and it is likely that the administration of estrogen may not only serve to demonstrate its presence at this time but that it actively causes the system to mature (STEELE and WEISZ, I974).

Similar considerations apply to immature female mice, in which the essential role of estrogen in the mediation of socially induced puberty has been confirmed (BRONSON, I975). The definition of the morphological substrate underlying this positive feedback response and of the mode of action of estrogen requires further study; both the hypothalamus (e.g. RAMIREZ and SAWYER, I974; LEGAN and KARSCH, I975 a), and the anterior pituitary gland (SMrth and DavidSON, I974, DÖCKE and DöRNER, 1974) have been proposed as estrogen effector sites and suggestions as to its mode of action include increased synthesis of the luteinizing hormone releasing hormone (LRH) (JACKSON, I972), changes in the threshold of excitability of central neurons (SAWYER, I970; LEGAN and KARSCH, I975a), interactions with hypothalamic adrenergic mechanisms (KALRA et al., I97I ; TALEISNIK et al., I97I) and modulation of pituitary responsiveness to LRH (e.g. AIYER et al., I974). In our hands, rats injected with $L R H$ at various times after the placement of a hypothalamic lesion consistently showed an impaired rather than an enhanced LH and FSH response (unpublished results) which suggest that pituitary. sensitization to LRH may not be a major factor in lesion-induced precocious puberty. As recently shown in rats (LEGAN and KARSCH, I975 b) and in pigs (FOXCROFT et al., 1975 ; POMERANTZ et al., I975) facilitatory effects of estrogen on gonadotropin release may be observed in the presence of depressed pituitary responsiveness to LRH. Whereas brain lesions readily induce precocious sexual maturation in the female rat, other species are notoriously refractory to this experimental manipulation, and this approach also fails completely in the male rat (CRITCHLOW and BARSELA, I967), though the male ferret appears to be responsive (BAUm and GolDFoor, 1974). It is conceivable that the female rat is predisposed to this response by her exceptionally short estrous cycle - which requires a particularly powerful stimulatory feedback system - whereas the male is refractory to lesions probably at least in part because he is unable to respond to gonadal steroids with a gonadotropin surge (CALigaris et al., 1972, I973).

Sexual Maturation 3rd workshop August 31, September 3, 1975 .

\section{ACKNOWLEDGEMEN'S}

The technical assistance of Miss Danielle CASSARD is gratefully acknowledged. This work was supported by grant no. 3.016.73 from the Swiss National Science Foundation and by a subsidy from the Société Académique de Genève. Radioimmunoassay reagents were generously provided by the NIAMDD-NIH Rat Pituitary Hormone Distribution Program. 


\section{RÉSUMÉ \\ PUBERTÉ PRÉCOCE CHEZ LA RATTE : MODE D'ACTION DES LÉSIONS HYPOTHALAMIQUES}

La sécrétion induite par la progestérone d'hormone lutéinisante (LH) et folliculo-stimulante (FSH) a été étudié chez des rattes prépubères, d'une part trois jours après une injection de ro $\mu \mathrm{g}$ d'œstrogène, et d'autre part trois jours après une lésion électrolytique de l'hypothalamus basal. Dans les deux cas, les valeurs plasmatiques de LH augmentent en comparaison avec celles rencontrées chez les animaux témoins. La FSH plasmatique a, quant à elle, augmenté trois fois après lésion/progestérone, et cinq fois lors du double traitement hormonal œestrogène/progestérone. Le poids de l'utérus reflétant l'exposition aux stéroïdes, endogènes ou exogènes, augmente de manière comparable dans les deux cas.

Nous concluons que ce type de lésion cérébrale est capable de remplacer une injection d'œestrogène pour permettre à la progestérone de déclencher une libération des gonadotrophines chez la ratte prépubère. Une lésion hypothalamique unilatérale près de la tige pituitaire, au $23^{e}$ jour de vie, agit comme une injection de Io $\mu \mathrm{g}$ de benzoate d'oestradiol le même jour.

Ces résultats accréditent notre thèse selon laquelle les lésions cérébrales accélèrent la maturation sexuelle chez la ratte, par une activation précoce de la stéroïdogenèse ovarienne plutôt que par la suppression d'une inhibition d'origine nerveuse sur le système reproducteur.

\section{REFERENCES}

Atyer M. S., Fink G., r974. The role of sex steroid hormones in modulating the responsiveness of the anterior pituitary gland to luteinizing hormone releasing factor in the female rat. $J$. Endocr., 62, 553-572.

BAum M. J., Golpfoot D. A., r974. Effect of hypothalamic lesions on maturation and annual cyclicity of the ferret testis. J. Endocr., 62, 59-73.

Bronson F. H., I975. Male-induced precocial puberty in female mice : confirmation of the role of estrogen. Endocrinology, 96, 5 I I-5I4.

Brown-Grant K., Exley D., Naftolin F., i97o. Peripheral plasma oestradiol and Iuteinizing hormone concentrations during the oestrus cycle of the rat. $J$. Endocr., 48, 295-296.

Caligaris L., Astrada J. J., Taleisnik S., I972. Influence of age on the release of luteinizing hormone induced by oestrogen and progesterone in immature rats. $J$. Endocr., 55, 97-103.

Caligaris L., Astrada J. J., Taleisnik S., 1973. Development of the mechanisms involved in the facilitatory and inhibitory effects of ovarian steroids on the release of follicle-stimulating hormone in the immature rat. J. Endocr., 58, 547-554.

Critchlow V., Bar-Sela M. E., 1967. Control of the onset of puberty, Ior-I62, in : Martini L., Ganong W. F., Neuroendocrinology, 2, Academic Press, New York.

Davidson J. M., I974. Hypothalamic-pituitary regulation of puberty, evidence from animal experimentation, 79-Io3, in : Grumbach M. M., Grave G. D., MaYer F. F., The Control of the Onset of Puberty, Wiley, New York.

Donovan B. T., Van Der Werfa Ten Bosch J. J., 1956. Precocious puberty in rats with hypothalamic lesions.' Nature (Lond.), 178, 745.

Donovan B. T., Van Der Werff Ten Bosch J. J., 196j. The Physiology of Puberly, Williams and Wilkins, Baltimore, Md.

Döcke F., Dörner G., r974. Oestrogen and the control of gonadotrophin secretion in the immature rat. J. Endocr., 63, 285-298.

EveretT J. W., Radford H. M., I961. Irritative deposits from stainless steel electrodes in the preoptic brain causing release of pituitary gonadotropin. Proc. Soc. Exp. Biol. Med., 108, 604-609.

Ferin M., Zimmering Paula E., Vande Wiele L., i969. Effects of antibodies to Estradiol-i7 $\beta$ on PMS-induced ovulation in immature rats. Endocrinology, 84, 893-9oo.

Foxcroft G. R., Pomerantz D. K., Nalbandov A. V., I975. Effects of estradiol-I73 on LH-RH/ FSH-RH-induced, and spontaneous LH release in prepubertal female pigs. Endocrinology, 96, $55 \mathrm{I}-557$. 
JAckson G. L., 1972. Effect of Actinomycin D on estrogen-induced release of luteinizing hormone in ovariectomized rats. Endocrinology, 91, 1284-I 287.

Kalra P. S., Krulich L., Quijada M., Kalra S. P., Fawcett C. P., McCann S. M., I97i. Feedback of gonadal steroids on gonadotropins and prolactin in the rat, 708-715, in : Proc. 3rd Int. Congr. Hormonal Steroids, Hamburg, ICS 219, Excerpta Medica, Amsterdam.

KITChen J. H., RuF K. B., Wilkinson M., 1975. Modulation by oestrogen of the rate of precocious sexual maturation in female rats induced by brain stimulation. J. Physiol. (Lond.), 249, 35-36 p.

Legan S. J., Karsch F. J., 1975 a. A daily signal for the LH surge in the rat. Endocrinology, 96, $57-62$.

LEGAN S. J., Karsch F. J., I975 $b$. Modulation of pituitary responsiveness to luteinizing hormonereleasing factor during the estrous cycle of the rat. Endocrinology, 96, 571-575.

Merk F. B., Botticelli C. R., Albright J. T., i972. An intracellular response to estrogen by granulosa cells in the rat ovary; an electron microscopic study. Endocrinology, 90, 992-I007.

Pomerantz D. K., Foxcroft G. R., Nalbandov A. V., r975. Acute and chronic estradiol-I7 $\beta$ inhibition of LH release in prepubertal female pigs : Time course and site of action. Endocrinology, 96, $558-563$.

Ramirez V. D., 1973. Endocrinology of Puberty, I-28, in : Greep R. O., Handbook of Physiology, Section 7, Vol. II, part I, American Physiological Society, Washington, D. C.

Ramirez V. D., Sawyer C. H., 1965. Advancement of puberty in the female rat by estrogen. Endocrinology, 76, II58-II68.

Ramirez V. D., SAWYer C. H., I974. Differential dynamic responses of plasma LH and FSH to ovariectomy and to a single injection of estradiol in the rat. Endocrinology, 94, 987-993.

Reiter E. O., Goldenberg R. L., Vaitukaitis J. L., Ros\$ G. T., I972. A role for endogenous estrogen in normal ovarian development in the neonatal rat. Endocrinology, 91, I537-I539.

RuF K. B., Younglai E. V., Holmes M. J., r974. Induction of precocious sexuel maturation in female rats by electrochemical stimulation of the brain. Brain Res, 78, 437-446.

Ruf K. B., Wilkinson M., de Ziegler D., I975 a. Brain lesions and precocious puberty in rats Nature (Lond.), 257, 404-405.

Ruf K. B., Kitchen J. H., Wilkinson M, I975 $b$. Synergistic effects of estrogen and brain stimulation on precocious sexual maturation in the female rat. Acta Endocr. (Kbh.) (in press).

SAWYER C. H., r97o. Electrophysiological correlates of release of pituitary ovulating hormones. Fed. Proc., 29, 1895-I899.

Smith E. R., DAvidson J. M., 1974. Location of feedback receptors : Effects of intracranially implanted steroids on plasma LH and LRF response. Endocrinology, 95, I566-I573.

Steele R. E., Weisz J., I974. Changes in sensitivity of the estradiol-LH feedback system with puberty in the female rat. Endocrinology, 95, 5 I3-520.

Taleisnik S., Caligaris L., Astrada J. J., ig7r. Feedback effects of gonadal steroids on the release of gonadotropins, 699-707, in : Proc. 3rd Int. Congr. Hormonal Steroids, Hamburg, ICS 219, Excerpta Medica, Amsterdam. 